\title{
Survey of HCMV in allogenic and autologous stem cell transplantation by real-time PCR in Kermanshah, west of Iran
}

\author{
Mehrdad Payandeh ${ }^{1}$, Mohammad Hossein Zamanian², Bizhan Nomanpour ${ }^{3}$, Mohammad Soroush Farhadi ${ }^{4}$ \\ Alireza Janbakhsh², Mosayeb Rostamian ${ }^{5}$, Azam Elahi ${ }^{6}$, Somayeh Jafari ${ }^{6}$ and Mohammad Dehghannejad ${ }^{7^{*}}$ (D)
}

\begin{abstract}
Introduction: Human Cytomegalovirus (HCMV) is the most important viral pathogen in people undergoing bone marrow transplantation (BMT). HCMV detection in the early stages makes is possible to save the patients' lives through immediate and timely treatment. The aim of this study was to investigate the status of HCMV using the real-time PCR method in BMT patients in Kermanshah, west of Iran.
\end{abstract}

Methods: HCMV monitoring was done in 120 patients who underwent BMT, 38 allogeneic cases and 82 autologous cases, using the ELISA serology test before transplantation. The participants were followed up 100 days after transplantation for HCMV detection in blood samples using real-time PCR. Preemptive therapy started with Ganciclovir and Foscarnet when the viral load was > 200 HCMV DNA copies/ml.

Results: Despite preemptive therapy, infection recurred in less than 1 month. HCMV recurred more frequently in patients undergoing allogenic transplation versus those receiving autologous transplantation. Recurrence was seen in 5 patients receiving allogenic transplantation. HCMV recurrence occurred in five patients with allogeneic transplantation. Twelve patients undergoing allogeneic or autologous transplantation (83\%) and a virus load of > 1000 copies/ml showed HCMV-related symptoms. Three patients died, two due to HCMV-related pneumonia and the other one due to a fungal infection.

Conclusion: Real-time PCR may be a useful method for quantification and monitoring of HCMV recurrence and may be helpful in choosing more efficient HCMV preemptive treatment in BMT recipients.

Keywords: Cytomegalovirus, Bone marrow transplant, Real-time PCR

\section{Introduction}

Cytomegalovirus (HCMV) is a member of the herpes virus family. This virus can affect various cells of the host body including endothelial, epithelial, and hematopoietic cells [1]. Antibodies against HCMV have been identified in the serum of $80 \%$ of healthy adults,

\footnotetext{
* Correspondence: drdehghannejad70@gmail.com

${ }^{7}$ Medical School of Kermanshah, Kermanshah University of Medical Sciences, Kermanshah, Iran

Full list of author information is available at the end of the article
}

indicating previous infection and the latency of the virus that could be reactivated [2].

In transplant recipients, suppression of the immune system triggers HCMV reactivation by both primary infections (i.e. infection in patients that are not detectable or sero-negative before transplantation) or secondary infections (i.e. infections due to the activation of a latent infection) [3]. Primary infection may cause different morbidities and even mortality in severe forms. It has a higher frequency, more clinical manifestations, and a higher recurrence rate than secondary infections $[4,5]$. 
Superinfection by HCMV occurs when a seropositive recipient $(\mathrm{R}+)$ receives cells from a seropositive donor $(\mathrm{D}+)$; therefore, the origin of $\mathrm{HCMV}$ is reactivated after transplantation [6].

Secondary and superinfections can lead to clinical manifestations of HCMV in approximately $30 \%$ of stem cell transplant recipients. Such patients usually show milder symptoms than those infected by primary infections [7]. Regardless of the previous seropositive status of the donor or the recipient, HCMV occurs in $30-50 \%$ of bone marrow allogeneic recipients, which may progress severe HCMV [8]. However, HCMV-related diseases are approximately two times more common in $\mathrm{D}+/ \mathrm{R}+$ patients than in $\mathrm{D}+/ \mathrm{R}$ - patients, which may be due to coincidence of active secondary infection and superinfection after transplantation [6].

HCMV infection is usually seen in the late postoperative period [8]. The onset of HCMV disease is often reported in a period of about 28 to 72 days after transplantation. It involves several organs including the lungs and intestines [9]. HCMV is associated with various complications such as pneumonia, gastrointestinal infections, central nervous system infections, and retinitis as well as many other miscellaneous disorders such as cystitis, nephritis, myocarditis, and pancreatitis [10]. New HCMV infection in a patient with former manifestations of the infection who did not have HCMV detected during active surveillance for an interval of at least 4 weeks is called "recurrent infection". Recurrent infection may be an outcome of reinfection (exogenous) or reactivation of the latent virus (endogenous) [10].

The strategy for HCMV treatment in transplantation is preemptive therapy, and various studies have shown that this strategy is preferable to public prophylaxis. Ganciclovir is usually used for preemptive therapy. Foscarnet is an alternative in drug resistant cases [11]. After transplantation, treatment should be initiated when the blood viral load reaches a significant level before the onset of clinical symptoms. Therefore, the HCMV load in the blood should be determined in this strategy $[12,13]$.

Monitoring the viral load is a valuable prognostic indicator for HCMV treatment and prevention [8, 14]. Several diagnostic methods are available for monitoring of the patients at risk for HCMV infection [8]. Serological methods are associated with false positive results and are only useful in the pre-transplant stage to detect the presence of anti-HCMV antibodies in donor and recipient individuals, as well as in blood transfusion [15]. The pp65 antigen test is another serological test that detects HCMV antigens on mononuclear cells in the peripheral blood. However, it has some limitations including being subjective, labor intensive nature of the test, relative lack of standardization, and lower sensitivity compared to PCR $[8,16]$.
Furthermore, culturing HCMV is a difficult and timeconsuming process and since the transplanted patients take immunosuppressive drugs, the viral growth is overwhelming [17].

Nowadays, real-time PCR is considered the standard method for determining the quantity of HCMV in the blood of patients with immune deficiency. This method is used to measure the DNA load in different samples. Real-time RCR has some advantages such as higher sensitivity and a limited turnaround time; hence, it has replaced the pp65 antigen test in many health centers around the world [8]. The aim of this study was to investigate the viral load of HCMV in bone marrow transplant patients.

\section{Methods}

Patients

This cross-sectional study was performed in the bone marrow transplant ward of Imam Reza Hospital, Kermanshah Province, west of Iran from April 2017 to May 2020. In total, 120 patients receiving bone marrow transplantation including allogeneic stem cell transplantation (alloSCT) and autologous SCT (autoSCT) were included in this study.

\section{HCMV surveillance}

Whole blood $(3-5 \mathrm{ml})$ samples with EDTA as anticoagulant were collected from patients presenting to the bone marrow transplant ward. The status of HCMV was tested in the serum of all SCT recipients and donors before transplantation to detect HCMV antibody using an ELISA kit (Diapro Kit, Italy). ELISA is the most frequent serologic test for assessing antibodies against HCMV. An ELISA positive test for HCMV antibodies shows that a person has been infected with HCMV during life but it does not show the time of infection.

The patients were categorized into four groups based on seronegativity or seropositivity of the recipient and donor before transplantation as R-D-, R+D-, R-D+ and $\mathrm{R}+\mathrm{D}+$ ).

\section{DNA extraction and real-time PCR}

Since HCMV-DNAemia is an independent risk factor for HCMV infection [18], virological surveillance for virus replication is routinely performed in the first 100 days post-transplant using real-time PCR for monitoring of HCMV-DNA in the blood samples.

Using $200 \mu \mathrm{l}$ of each patient's plasma sample, HCMV genomic DNA was extracted using QIAamp DNA mini kit (Qiagen, Germany) according to the manufacturer's instructions. TaqMan ${ }^{\circ}$-MGB probed real-time PCR was applied using HCMV RQ PCR kit (Novin-Gene, Iran) according to the manufacturer's instructions. The limit of detection (LOD) of the kit was 200 copies /ul. 
The thermal cycling program started with $10 \mathrm{~min}$ at $95^{\circ} \mathrm{C}$ for initial denaturation followed by 45 cycles of denaturation $\left(15 \mathrm{~s}\right.$ at $\left.95^{\circ} \mathrm{C}\right)$, annealing $\left(60 \mathrm{~s}\right.$ at $\left.58^{\circ} \mathrm{C}\right)$, and extension $\left(30 \mathrm{~s}\right.$ at $\left.58^{\circ} \mathrm{C}\right)$. The program was run in the ABI Step One Plus real-time PCR (Applied Biosystems, USA) in triplicate. To quantify HCMV loads, a standard curve was created using standards of the kit that contained 10,000, 1000, 100, and 10 virus DNA copies/ul.

The results were included when the efficiency (E) was more than $90 \%$ and R2 was more than $88 \%$.

\section{Prophylactic strategies}

Based on prophylactic or preemptive tests, preemptive therapy started when $>200$ virus DNA copies/ul [19] were detected in the serum using $10 \mathrm{mg} / \mathrm{kg}$ Ganciclovir or $180 \mathrm{mg} / \mathrm{kg}$ Foscarnet once a day for $2-3$ weeks. Then, Ganciclovir $5 \mathrm{mg} / \mathrm{kg}$ or Foscarnet $90 \mathrm{mg} / \mathrm{kg}$ was given daily until two consecutive negative viral loads were obtained.

\section{Ethical consideration}

The Ethics Committee of Kermanshah University of Medical Sciences, Kermanshah, Iran approved the study (ethics code: IR.KUMS. 980,164). Written informed consent was obtained from all patients for participation in the study.

\section{Results}

\section{Patients}

Of the 120 patients receiving bone marrow transplants, $82(68.3 \%)$ were male and $38(31.6 \%)$ were female. The mean age of the patients was $47.7 \pm 13.38$ years. Fifty-six patients $(46.6 \%)$ had multiple myeloma (MM), 24 patients (20\%) had Hodgkin's lymphoma, 21 patients (17.5\%) had acute myeloid leukemia (AML), 10 patients (8.3\%) had non-Hodgkin's lymphoma, 6 patients (5\%) had acute lymphocytic leukemia (ALL), and 3 patients (2.5\%) had myelofibrosis (MF).

Thirty-six patients (30\%) had underlying diseases such as hypertension, high blood sugar, and abnormal lipid profile. Moreover, 76 patients (63\%) were sero-positive for HCMV. Thirty-eight patients (31.6\%) received allogeneic transplantation and $82(68.3 \%)$ received autologous transplantation (Table 1).

\section{AlloSCT patients - HCMV recurrence}

In the follow-up period (median 100 days after transplantation), HCMV DNA was detected in $23(60 \%)$ cases. The time between the transplantation day and the day of first HCMV positive detection was defined as time to infection (TTI). The median TTI was 27.9 days (range: 4 to 100 days) and the median viral load was $2.4 \times 10^{4}$ copies/ul (range: 23 to $3.3 \times 10^{5}$ copies/ul). HCMV recurrence was observed in five patients $(21.7 \%)$
Table 1 Patient characteristics

\begin{tabular}{lll}
\hline Variables & Frequency & Percent \\
\hline Sex & 82 & \\
Male & 38 & $68.3 \%$ \\
Female & 36 & $31.6 \%$ \\
Underlying disease & $30 \%$ \\
Type of bone marrow transplant & \\
$\quad$ autoSCT & 82 & $68.3 \%$ \\
$\quad$ alloSCT & 38 & $31.6 \%$ \\
HCMV & & \\
Serostatus & 21 & $17.5 \%$ \\
$\quad$ real time PCR & 28 & $23.3 \%$ \\
Death & 3 & $2.5 \%$ \\
sum & 120 & 100 \\
\hline
\end{tabular}

that were high risk for HCMV recurrence, three of whom had AML, one had relapsed MM and one had relapsed MF (Table 2). HCMV recurrence occurred at least 2 to 3 weeks after transplantation.

In alloSCT patients, HCMV led to kidney diseases such as cystitis or hematuria (10 cases), gastrointestinal disorders such as diarrhea (2 cases), pneumonia (2 cases), liver disorders (2 cases), CNS disorders (1 case) and fungal infections ( 1 case). The viral load was $>1000$ copies/ul in 9 of these patients. Only one case had a lower viral load that died from fungal infections. The mortality rate was 2 cases (8.6\%) in 100 days of followup.

\section{AutoSCT patients - recurrence of HCMV}

Of 82 autoSCT patients, 51cases (62\%) were HCMV seropositive, indicating previous exposure to the virus. HCMV DNA was detected in $5(6 \%)$ cases. The median TTI in these patients was 10 days (range: 1 to 26 days) and the median viral load was 688.8 DNA copies/ul (range: 50 to $2.3 \times 10^{3}$ DNA copies/ul). No HCMV recurrence was observed in any of the autoSCT patients (Table 3).

Two patients with a viral load of $>200$ DNA copies/ul developed HCMV-related complications, including pneumonia and gastrointestinal disorders (colitis and diarrhea). One of these patients did not respond well to treatment and died, but the other one responded to treatment and survived.

\section{Discussion}

Although results of studies investigating HCMV complications in bone marrow stem cell recipients are very challenging, significant progress has been made in reducing the clinical effects of the infection in low- to moderate-risk recipients. However, the recipients are 
Table 2 Patient characteristics (alloSCT patients) with positive HCMV real-time PCR result

\begin{tabular}{|c|c|c|c|c|c|c|c|c|c|c|}
\hline $\begin{array}{l}\text { Patient } \\
\text { No. }\end{array}$ & $\begin{array}{l}\text { Age } \\
\text { and } \\
\text { Sex }\end{array}$ & Disease & Donor & $\begin{array}{l}\text { Underlying } \\
\text { disease }\end{array}$ & $\begin{array}{l}\text { Day of first } \\
\text { positive RT-PCR } \\
\text { result }\end{array}$ & $\begin{array}{l}\text { Peak HCMV } \\
\text { level (copies/ } \\
\mathrm{ml} \text { ) }\end{array}$ & Recurrence & $\begin{array}{l}\text { HCMV } \\
\text { Serostatus } \\
\text { (D/R) }\end{array}$ & GVHD & Outcome \\
\hline 1 & $42 \mathrm{M}$ & AML & Sister & + & 38 & $88,600 \pm 15$ & - & $-1-$ & - & Alive (Hematuria) \\
\hline 2 & $32 \mathrm{M}$ & ALL & Mud & - & 23 & $4000 \pm 8$ & - & $-/+$ & - & $\begin{array}{l}\text { Alive (Liver } \\
\text { disorders) }\end{array}$ \\
\hline 3 & $48 \mathrm{M}$ & MM & Brother & - & 96 & $64 \pm 1$ & - & $+/+$ & - & Alive \\
\hline 4 & $56 \mathrm{M}$ & AML & Brother & - & 10 & $230 \pm 2$ & + & $+/+$ & Skin & Alive \\
\hline 5 & $40 \mathrm{M}$ & AML & Brother & - & 4 & $835 \pm 1$ & - & $+/+$ & - & Alive \\
\hline 6 & $33 \mathrm{~F}$ & ALL & Brother & - & 4 & $480 \pm 2$ & - & $-1-$ & Gl & Alive \\
\hline 7 & $41 \mathrm{M}$ & ALL & Brother & + & 10 & $563 \pm 3$ & - & $-1+$ & Skin & Alive \\
\hline 8 & $42 \mathrm{M}$ & ALL & Brother & - & 100 & $670 \pm 1$ & - & $+/+$ & Compound & Alive \\
\hline 9 & $21 \mathrm{M}$ & AML & Brother & - & 40 & $120 \pm 1$ & - & $-1+$ & Compound & Alive \\
\hline 10 & $37 \mathrm{M}$ & AML & Brother & - & 7 & $300 \pm 1$ & - & $+/+$ & - & Alive \\
\hline 11 & $26 \mathrm{M}$ & AML & Brother & - & 28 & $117,413 \pm 16$ & - & $+/+$ & - & Alive (Diarrhea) \\
\hline 12 & $50 \mathrm{M}$ & AML & Mud & + & 56 & $580 \pm 1$ & + & $-1+$ & Compound & Alive \\
\hline 13 & $46 \mathrm{M}$ & AML & Sister & - & 30 & $4320 \pm 3$ & - & $-1+$ & - & $\begin{array}{l}\text { Died Of Fungal } \\
\text { Complications }\end{array}$ \\
\hline 14 & $53 \mathrm{M}$ & MF & Mud & + & 9 & $8310 \pm 11$ & + & $-1+$ & Compound & $\begin{array}{l}\text { Alive (CNS } \\
\text { disorders) }\end{array}$ \\
\hline 15 & $57 \mathrm{~F}$ & AML & Mud & + & 12 & $315 \pm 2$ & - & $-1+$ & Compound & Alive \\
\hline 16 & $39 M$ & AML & Brother & - & 8 & $23 \pm 0$ & - & $+/+$ & Skin & Alive \\
\hline 17 & $46 \mathrm{~F}$ & ALL & Brother & + & 19 & $191 \pm 0$ & - & $+/+$ & Gl & Alive \\
\hline 18 & $46 \mathrm{~F}$ & AML & Mud & - & 18 & $325,967 \pm 25$ & + & $+/+$ & Gl & Alive (Pneumonitis) \\
\hline 19 & $58 \mathrm{~F}$ & MM & Mud & - & 38 & $6174 \pm 13$ & - & $+/+$ & Skin & $\begin{array}{l}\text { Alive (Digestive } \\
\text { disorders) }\end{array}$ \\
\hline 20 & $30 \mathrm{M}$ & MM & Sister & + & 11 & $39 \pm 0$ & - & $-1-$ & - & Alive \\
\hline 21 & $31 \mathrm{~F}$ & MM & Mud & - & 26 & $6579 \pm 5$ & + & $+/+$ & Gl & $\begin{array}{l}\text { Alive (Hemorrhagic } \\
\text { cystitis, Kidney } \\
\text { failure) }\end{array}$ \\
\hline 22 & $55 \mathrm{~F}$ & $\mathrm{NHL}$ & Sister & - & 25 & $452 \pm 1$ & - & $+/-$ & - & Dead (Pneumonitis) \\
\hline 23 & $67 \mathrm{M}$ & AML & Sister & - & 31 & $250 \pm 2$ & - & $-1-$ & - & Alive \\
\hline
\end{tabular}

MUD Matched Unrelated Donor, $R$ - Recipient HCMV negative, $D$ - Donor HCMV negative, $R+$ Recipient HCMV positive, $D+$ Donor HCMV positive, HCMV Cytomegalovirus, AML Acute Myeloid Leukemia, CML Chronic Myeloid Leukemia, ALL Acute Lymphoblastic Leukemia, MM Multiple Myeloma, HL Hodgkin Lymphoma, NHL Non-Hodgkin Lymphoma, MF Myelofibrosis, GVHD Graft-Versus-Host Disease, PCR Polymerase Chain Reaction

Table 3 Patient characteristics (autoSCT patients) with positive HCMV real-time PCR result

\begin{tabular}{|c|c|c|c|c|c|c|c|c|}
\hline $\begin{array}{l}\text { Patient } \\
\text { No. }\end{array}$ & $\begin{array}{l}\text { Age and } \\
\text { Sex }\end{array}$ & Disease & $\begin{array}{l}\text { Underlying } \\
\text { disease }\end{array}$ & $\begin{array}{l}\text { Day of first positive RT- } \\
\text { PCR result }\end{array}$ & $\begin{array}{l}\text { Peak HCMV level } \\
\text { (copies/ml) }\end{array}$ & Recurrence & $\begin{array}{l}\text { HCMV } \\
\text { Serostatus }\end{array}$ & Outcome \\
\hline 1 & $49 M$ & $\mathrm{HL}$ & - & 26 & $846 \pm 3$ & - & + & $\begin{array}{l}\text { Dead } \\
\text { (Pneumonitis) }\end{array}$ \\
\hline 2 & $51 \mathrm{~F}$ & $\mathrm{MM}$ & - & 4 & $50 \pm 0$ & - & - & Alive \\
\hline 3 & $63 \mathrm{M}$ & MM & - & 17 & $2366 \pm 4$ & - & + & $\begin{array}{l}\text { Alive (Colitis and } \\
\text { Diarrhea) }\end{array}$ \\
\hline 4 & $67 \mathrm{~F}$ & $\mathrm{MM}$ & - & 2 & $125 \pm 1$ & - & - & Alive \\
\hline 5 & $55 \mathrm{~F}$ & $\mathrm{NHL}$ & - & 1 & $57 \pm 0$ & - & + & Alive \\
\hline
\end{tabular}


still at risk for HCMV infection and its indirect effects due to severe suppression of the immune system [20].

Quantitative measurement of HCMV in the blood by real-time PCR is very helpful in diagnosing HCMV, predicting the prognosis of HCMV before symptoms occur, and evaluating response to treatments [21]. Early detection of HCMV infection leads to prophylaxis or preventive prescription earlier than treatment, which can reduce both the severity of HCMV complications and HCMVrelated mortality [22, 23]. However, despite advances in HCMV prevention, it is still an important cause of mortality in immune suppressed patients [24].

HCMV infection can be in the form of primary infection, virus reactivation, or superinfection. In case of bone marrow transplantation, the serological status of the recipient is a significant risk factor for HCMV reactivation, transplantation rejection, and the recipient's mortality [25-27].

In the present study, in low-risk allograft cases where both donors and recipients were ELISA negative (R-/D-) before transplantation, real-time PCR evidence showed HCMV contamination of the recipients after transplantation. Similarly, Butt et al. reported that $55 \%$ of their low-risk (R-/D-) patients were HCMV positive after transplantation according to real-time PCR results [4].

The origin of HCMV is unclear in these cases, but it may be transmitted by blood products after transplantation. Moreover, the donor or the recipient may already have a HCMV infection but be a weak producer of HCMV antibodies, so they may be misdiagnosed as HCMV negative cases using techniques that rely on antibody detection such as ELISA. Many bone marrow transplantation patients are suppressed by previous chemotherapy, which may lead to a decrease in HCMV antibody titer and misdiagnosis of an $\mathrm{R}+$ patient as a low-risk recipient.

The risk of HCMV reactivation has been also shown in autologous bone marrow transplantation where seronegative patients are infected with HCMV after transplantation. This condition is mainly observed when methods other than RT-PCR are used. Most studies using RT-PCR suggest a percentage of post-ASCT HCMV DNA infections of about 9.1-17.6\% [28-31], which is more frequently observed in HCMV IgG seropositive patients [30]. In our study, only $6 \%$ of the patients had a post-ASCT HCMV DNA infection, which is lower than the average values reported in other studies. The reason for this discrepancy is not known but it may be related to differences in experimental settings such as sample size, materials and methods used, etc.

Previous studies reported an incidence of $0-22 \%$ for HCMV infection in transplantation patients [32]. There are also other factors involved in HCMV infection in these patients such as heavy diets, type of medications, etc. [33, 34] Attention to these factors may be helpful in HCMV screening of all bone marrow transplantation patients at the initial diagnosis steps.

HCMV infection is usually asymptomatic, but it sometimes occurs in some patients in the form of a serious and fatal infection. The most common manifestations of HCMV infection are pneumonia and gastrointestinal disease (which may involve any organ from the esophagus to the large intestine) [20]. In our study, HCMV caused disease in 12 cases with the most common symptoms being pneumonia and gastrointestinal disorders. Three patients died, two from pneumonia and one from a fungal infection. Previous studies have shown that most HCMV-related deaths were due to bacterial and fungal sepsis, confirming an association between HCMV and other opportunistic infections. The incidence of graft versus host disease (GVHD) is also indirectly associated with HCMV infection [20].

One of the most important factors in predicting lack of response to HCMV antiviral therapy is the pretreatment viral load. The optimal threshold of the viral load to start antiviral therapy in hematopoietic cell transplant (HCT) recipients has not yet been determined [35]. Our findings are in line with previous reports in which HCMV treatment has been associated with shorter viremia episodes and shorter courses of antiviral therapy [36, 37]. High-risk allogeneic recipients require longer exposure to antiviral therapy because HCMV is often present in a longer period of time in these patients [35]. A study by Camargo et al. showed that antiviral therapy in high-risk patients with an antibody level of $\geq 150 \mathrm{IU} / \mathrm{mL}$ should not be delayed for the first 100 days after transplantation [35]. Furthermore, Green et al. found that early initiation of antiviral therapy was not only useful but also well tolerated by the patients [28]. Green et al. reported an association between a viral load of $\geq 250 \mathrm{IU} / \mathrm{mL}$ and increased risk of mortality in the early postoperative period [38]. Camargo et al. also found a high probability of asymptomatic mortality in patients who failed to eradicate the HCMV virus [35].

Identifying the cutoff level for real time PCR test could be an important indicator of the proper time to start anti-HCMV treatment [39]. Using real time PCR, Mhiri et al. determined a cut-off value of above 400 DNA copies $/ \mathrm{ml}$ in plasma samples [40].

Garrigue et al. and Ghaffari et al. reported a cut-off value of 6300 and 1000 DNA copies/ml for HCMV infection using real-time PCR, respectively [28, 41]. However, it is not possible to establish a universal cut-off value for the initiation of anti-HCMV treatment and it seems that the cut-off value should be confirmed by testing many patients in each study [39].

According to a study by Mhiriet al., the initial load of HCMV is significantly associated with the progression of 
the disease [40]. Weinberg et al. found that patients with recurrent HCMV were still positive for real-time PCR at the time of treatment discontinuation, while patients who did not experience recurrence tended to clear HCMV faster [42].

Numerous studies have shown that the risk of developing HCMV is directly associated with the viral load $[35,38]$. However, in the present study, even patients with low viral loads developed HCMV infection, emphasizing the importance of early initiating of antiviral therapy.

In the present study, $71 \%$ of HCMV positive cases had a viral load of above $2 \times 10^{2}$ DNA copies $/ \mathrm{mL}$ and HCMV recurrence was seen in $21 \%$ of the patients. Furthermore, $83 \%$ of the recipients were seropositive and two of them died, one with less than 1000 HCMV DNA copies/ml. Similar to our results, Banon et al. found HCMV-related diseases in three cases $(8.7 \%)$ with less than 1000 HCMV DNA copies/ml [43]. In addition, several cohort studies have shown that HCMV presence or reactivation is associated with an increased risk of asymptomatic mortality $[44,45]$.

In the present study, the time between the transplantation and first detection of HCMV DNA was about 1 month in allogeneic transplant cases and about 10 days in autologous transplant cases. This indicates that due to immunosuppression, HCMV infection is more common in the first 3 months after transplantation, which is in accordance with previous reports [46].

Due to the limited availability of antiviral drugs, preemptive therapy has become the standard of care for the prevention of HCMV following blood cell transplantation [35]. Real-time PCR can be used as a potential method for screening patients at regular intervals, and if a positive result is observed, the sequential evaluation process should begin. This strategy can lead to much earlier antiviral treatment. Therefore, attention should be paid to the viral load by regular check-ups of the patients, even when their viral load is negative, to effectively control this disease.

\section{Conclusion}

This study confirms the importance of viral load in the pathogenesis of HCMV after stem cell transplantation. Quantitative real-time PCR may be a useful tool for monitoring HCMV recurrence and response to antiviral therapy in bone marrow transplant recipients. The high incidence of seropositive HCMV in bone marrow transplant candidates confirms the need for an appropriate program to prevent HCMV-related complications through early diagnosis and treatment.

\section{Acknowledgments}

The authors wish to thank the Clinical Research Development Center of Imam Reza Hospital for their support. The authors would like to extend their gratitude to all the patients who participated in this study.

\section{Authors' contributions}

Mehrdad Payandeh: Supervision, Writing - Review \& Editing. Mohammad Hossein Zamanian: Data curation. Bijan Noemanpour: Data curation, Roles/ Writing - Original draft. Mohammad Soroush Farhadi: Funding acquisition, Resources. Alireza Janbakhsh: Methodology. Mosayeb Rostamian: Writing Review \& Editing. Azam Elahi: Project administration. Somayeh Jafari: Conceptualization, Data curation. Mohammad Dehghannejad: Writing Review \& Editing. The author(s) read and approved the final manuscript.

\section{Competing interests}

The authors declare no competing interest.

\section{Author details}

${ }^{1}$ Hematology and Medical Oncology Dept., Kermanshah University of Medical Sciences, Kermanshah, Iran. ${ }^{2}$ Infectious Diseases Dept., School of Medicine, Kermanshah University of Medical Sciences, Kermanshah, Iran. ${ }^{3}$ Microbiology Dept., Medical school of Kermanshah, Kermanshah University of Medical Sciences, Kermanshah, Iran. ${ }^{4}$ Microbiology Dept., Islamic Azad University, Tehran North Branch, Tehran, Iran. ${ }^{5}$ Infectious Diseases Research Center, Health Institute, Kermanshah University of Medical Sciences, Kermanshah, Iran. ${ }^{6}$ Clinical Research Development Center, Imam Reza Hospital, Kermanshah University of Medical Sciences, Kermanshah, Iran. ${ }^{7}$ Medical School of Kermanshah, Kermanshah University of Medical Sciences, Kermanshah, Iran.

Received: 13 October 2020 Accepted: 27 January 2021

Published online: 02 February 2021

\section{References}

1. Sinclair J. Human cytomegalovirus: latency and reactivation in the myeloid lineage. J Clin Virol. 2008;41(3):180-5.

2. Marchetti S, Santangelo R, Manzara S, D'onghia S, Fadda G, Cattani P. Comparison of real-time PCR and pp65 antigen assays for monitoring the development of Cytomegalovirus disease in recipients of solid organ and bone marrow transplants. New Microbiol. 2011;34(2):157-64.

3. Bennett J, Dolin R, Blaser M. Mandell, Douglas, and bennett's principles and practice of infectious diseases. 8th ed. Philadelphia: Saunders; 2014. p. 4572.

4. Butt NM, Clark RE. High frequency of positive surveillance for cytomegalovirus (CMV) by PCR in allograft recipients at low risk of CMV. Bone Marrow Transplant. 2001;27:615-9.

5. Seitz R. Human Cytomegalovirus (HCMV)-Revised. Transfus Med Hemother. 2010;37:365-75 Karger Publishers.

6. Azevedo LS, Pierrotti LC, Abdala E, Costa SF, Strabelli TMV, Campos SV, et al. Cytomegalovirus infection in transplant recipients. Clinics. 2015;70:515-23 Available from: https://pubmed.ncbi.nlm.nih.gov/26222822/. Cited 2020 Dec 16. Universidade de Sao Paulo.

7. Ljungman P, Hakki M, Boeckh M, et al. Hematol Oncol Clin North Am. 2011; 25:151-69 NIH Public Access.

8. Bhat V, Joshi A, Sarode R, Chavan P. Cytomegalovirus infection in the bone marrow transplant patient. World J Transplant. 2015;5(4):287-91.

9. Schulenburg A, Watkins-Riedel T, Greinix HT, Rabitsch W, Loidolt H, Keil F, et al. CMV monitoring after peripheral blood stem cell and bone marrow transplantation by pp65 antigen and quantitative PCR. Bone Marrow Transplant. 2001;28(8):765-8.

10. Ljungman P, Griffiths P, Paya C. Definitions of cytomegalovirus infection and disease in transplant recipients. Clin Infect Dis. 2002;34:1094-7.

11. Asberg A, Humar A, Jardine A, Rollag H, Pescovitz M, Mouas H, et al. Longterm outcomes of CMV disease treatment with Valganciclovir versus IV ganciclovir in solid organ transplant recipients. Am J Transplant. 2009;9(5): 1205-13.

12. Khansarinejad B, Soleimanjahi H, Mirab Samiee S, Hamidieh AA, Paryan M, Sanahmadi Y. Quantitation of human cytomegalovirus DNA in plasma using an affordable in-house qPCR assay. J Virol Methods. 2012;183(2):170-5.

13. Gerna G, Lilleri D, Furione M, Baldanti F. Management of human cytomegalovirus infection in transplantation: validation of virologic cut-offs 
for preemptive therapy and immunological cut-offs for protection. New Microbiol. 2011;34(3):229-54.

14. Razonable RR, Hayden RT. Clinical utility of viral load in management of cytomegalovirus infection after solid organ transplantation. Clin Microbiol Rev. 2013;26:703-27 American Society for Microbiology (ASM).

15. A. Ross $S$, Novak Z, Pati S, B. Boppana S. Overview of the diagnosis of Cytomegalovirus infection. Infect Disord - Drug Targets. 2012;11(5):466-74.

16. Breda G, Almeida B, Carstensen S, Bonfim CM, Nogueira MB, Vidal LR, et al. Human cytomegalovirus detection by real-time PCR and pp65-antigen test in hematopoietic stem cell transplant recipients: A challenge in low and middle-income countries. Pathog Glob Health. 2013;107(6):312-9.

17. Sia IG, Patel R. New strategies for prevention and therapy of cytomegalovirus infection and disease in solid-organ transplant recipients. Clin Microbiol Rev. 2000;13(1):83-121. https://doi.org/10.1128/cmr.13.1.83121.2000.

18. Gao XN, Lin J, Wang LJ, Li F, Li HH, Wang SH, et al. Risk factors and associations with clinical outcomes of cytomegalovirus reactivation after haploidentical versus matched-sibling unmanipulated PBSCT in patients with hematologic malignancies. Ann Hematol. 2020;99(8):1883-93. https://doi.org/10.1007/s00277-020-04156-6 Cited 2021 Jan 1.

19. Waggoner J, Ho DY, Libiran P, Pinsky BA. Clinical significance of low cytomegalovirus DNA levels in human plasma. J Clin Microbiol. 2012;50(7): 2378-83. https://doi.org/10.1128/JCM.06800-11.

20. Boeckh M, Nichols WG, Papanicolaou G, Rubin R, Wingard JR, Zaia J. Cytomegalovirus in hematopoietic stem cell transplant recipients: current status, known challenges, and future strategies. Biol Blood Marrow Transplant. 2003;9(9):543-58.

21. Zaia JA. Prevention of Cytomegalovirus disease in hematopoietic stem cell transplantation. Clin Infect Dis. 2002;35:999-1004.

22. Einsele $H$, Ehninger $G$, Hebart $H$, Wittkowski KM, Schuler U, Jahn G, et al. Polymerase chain reaction monitoring reduces the incidence of cytomegalovirus disease and the duration and side effects of antiviral therapy after bone marrow transplantation. Blood. 1995;86(7):2815-20

23. Ljungman P, Aschan J, Lewensohn-Fuchs I, Carlens S, Larsson K, Lönnqvist B, et al. Results of different strategies for reducing cytomegalovirus-associated mortality in allogeneic stem cell transplant recipients. Transplantation. 1998; 66(10):1330-4.

24. de la Cámara R. CMV in hematopoietic stem cell transplantation. Mediterr J Hematol Infect Dis. 2016;8(1):e2016031. https://doi.org/10.4084/MJHID.2016.031.

25. Lin TS, Zahrieh D, Weller E, Alyea EP, Antin JH, Soiffer RJ. Risk factors for cytomegalovirus reactivation after $\mathrm{CD} 6+\mathrm{T}$-cell??? depleted allogeneic bone marrow transplantation1. Transplantation. 2002;74(1):49-54 Available from: http://journals.Iww.com/00007890-200207150-00009. Cited 2020 May 1.

26. Saaverda S, Jarque I, Sanz GF, Moscardo F, Jiménez C, Martín G, et al. Infectious complications in patients undergoing unrelated donor bone marrow transplantation: experience from a single institution. Clin Microbiol Infect. 2002;8(11):725-33.

27. George B, Mathews V, Srivastava A, Chandy M. Infections among allogeneic bone marrow transplant recipients in India. Bone Marrow Transplant. 2004; 33(3):311-5

28. Green ML, Leisenring W, Stachel D, Pergam SA, Sandmaier BM, Wald A, et al. Efficacy of a viral load-based, risk-adapted, preemptive treatment strategy for prevention of Cytomegalovirus disease after hematopoietic cell transplantation. Biol Blood Marrow Transplant. 2012;18(11):1687-99.

29. Piukovics K, Terhes G, Gurbity-Pálfi T, Bereczki Á, Rárosi F, Deák J, et al. Cytomegalovirus infection in patients with haematological diseases and after autologous stem cell transplantation as consolidation: a single-centre study. Ann Hematol. 2017;96(1):125-31 Available from: https://pubmed.ncbi. nlm.nih.gov/27730340/. Cited 2020 Dec 16.

30. Marchesi F. Cytomegalovirus reactivation after autologous stem cell transplantation in myeloma and lymphoma patients: A single-center study. World J Transplant. 2015;5(3):129 Available from: /pmc/articles/PMC4580927/ ?report=abstract. Cited 2020 Dec 16.

31. Al-Rawi O, Abdel-Rahman F, Al-Najjar R, Abu-Jazar H, Salam M, Saad M. Cytomegalovirus reactivation in adult recipients of autologous stem cell transplantation: A single center experience. Mediterr J Hematol Infect Dis. 2015;7(1) Available from: /pmc/articles/PMC4560259/?report=abstract. Cited 2020 Dec 16.

32. Razonable REV. Management of CMV infection and disease in transplant patients. 27-29 February 2004 | Request PDF; 2004. p. 77-86. Available from: https://www.researchgate.net/publication/7782222_Management_of_CMV_
infection_and_disease_in_transplant_patients_27-29_February_2004. Cited 2020 May 1

33. Konoplev S, Champlin RE, Giralt S, Ueno NT, Khouri I, Raad I, et al. Viral infections Cytomegalovirus pneumonia in adult autologous blood and marrow transplant recipients. Bone Marrow Transplant. 2001;27 Available from: www.nature.com/bmt. Cited 2020 May 1.

34. Martinelli G, Agazzi A, Laszlo D, Santoro P, Mancuso P, Pruneri GC, et al. Idarubicin containing regimen in multiple myeloma: preliminary results of a pilot study using a modified "TANDEM" transplant program. Leuk Lymphoma. 2003;44(2):299-302.

35. Camargo JF, Kimble E, Rosa R, Shimose LA, Bueno MX, Jeyakumar N, et al. Impact of Cytomegalovirus viral load on probability of spontaneous clearance and response to preemptive therapy in allogeneic stem cell transplantation recipients. Biol Blood Marrow Transplant. 2018;24(4):806-14.

36. Milano F, Pergam SA, Xie H, Leisenring WM, Gutman JA, Riffkin I, et al. Intensive strategy to prevent CMV disease in seropositive umbilical cord blood transplant recipients. Blood. 2011;118(20):5689-96.

37. Tan SK, Waggoner JJ, Pinsky BA. Cytomegalovirus load at treatment initiation is predictive of time to resolution of viremia and duration of therapy in hematopoietic cell transplant recipients. J Clin Virol. 2015;69:17983.

38. Green ML, Leisenring W, Xie H, Mast TC, Cui Y, Sandmaier BM, et al. Cytomegalovirus viral load and mortality after haemopoietic stem cell transplantation in the era of pre-emptive therapy: a retrospective cohort study. Lancet Haematol. 2016;3(3):e119-27.

39. Ghaffari SH, Obeidi N, Dehghan M, Alimoghaddam K, Gharehbaghian A, Ghavamzadeh A. Monitoring of cytomegalovirus reactivation in bone marrow transplant recipients by real-time PCR. Pathol Oncol Res. 2008;14(4): 399-409.

40. Mhiri L, Kaabi B, Houimel M, Arrouji Z, Slim A. Comparison of pp65 antigenemia, quantitative PCR and DNA hybrid capture for detection of cytomegalovirus in transplant recipients and AIDS patients. J Virol Methods. 2007;143(1):23-8 Available from: https://linkinghub.elsevier.com/retrieve/pii/ S016609340700064X. Cited 2020 May 1.

41. Garrigue I, Doussau A, Asselineau J, Bricout H, Couzi L, Rio C, et al. Prediction of cytomegalovirus (CMV) plasma load from evaluation of CMV whole-blood load in samples from renal transplant recipients. J Clin Microbiol. 2008;46(2):493-8.

42. Weinberg A, Hodges TN, Li S, Cai G, Zamora MR. Comparison of PCR, Antigenemia assay, and rapid blood culture for detection and prevention of Cytomegalovirus disease after lung transplantation. J Clin Microbiol. 2000; 38(2):768.

43. Bonon SHA, Menoni SMF, Rossi CL, De Souza CA, Vigorito AC, Costa DB, et al. Surveillance of cytomegalovirus infection in haematopoietic stem cell transplantation patients. J Inf Secur. 2005;50(2):130-7.

44. Özdemir E, Saliba RM, Champlin RE, Couriel DR, Giralt SA, de Lima M, et al. Risk factors associated with late cytomegalovirus reactivation after allogeneic stem cell transplantation for hematological malignancies. Bone Marrow Transplant. 2007:40(2):125-36.

45. Mariotti J, Maura F, Spina F, Roncari L, Dodero A, Farina L, et al. Impact of cytomegalovirus replication and cytomegalovirus serostatus on the outcome of patients with B cell lymphoma after allogeneic stem cell transplantation. Biol Blood Marrow Transplant. 2014;20(6):885-90.

46. Diaz L, Rosales J, Rosso F, Rosales M, Estacio M, Manzi E, et al. Cytomegalovirus disease in patients with hematopoietic stem cell transplantation, experience over 8 years. Hematol Transfus Cell Ther. 2020; $42(1): 18-24$.

\section{Publisher's Note}

Springer Nature remains neutral with regard to jurisdictional claims in published maps and institutional affiliations. 